\title{
Frost-table and Thaw Depths in the Littoral Zone near Peard Bay, Alaska
}

\author{
E. H. OWENS and J. R. HARPER ${ }^{1}$
}

\begin{abstract}
Measurements were made of thaw depths and of sub-surface temperatures along four beach profiles, between late May and late August. On the upper beach levels, thaw proceeded rapidly following the disappearance of surface snow, but then became much slower. Near the water line, thaw was delayed by the presence of beach-fast ice, but thereafter increased steadily to greater depths than on the upper beach. Greater thaw depths were reached on barrier beaches than on beaches backed by tundra. On the upper beach, thaw depths and zero-degree depths did not differ significantly, but near the water line they were at variance due to the presence of saline pore waters.
\end{abstract}

RESUMÉ. Table de gel et profondeurs du dégel dans la zone du littoral, près de Peard Bay, Alaska. On mesura, sur une période s'étendant de la fin mai à la fin août et le long de quatre lignes tracées en travers des plages, les profondeurs respectives des zones de dégel, ainsi que les températures profondes correspondantes. A des niveaux de plage élevés, le dégel se poursuivit rapidement après la disparition de la neige de surface, pour ensuite se ralentir considérablement. Par contre, le long du rivage, le dégel se poursuivit lentement tant qu'il restait de la glace dans la mer, mais ensuite, la profondeur du dégel augmenta considérablement pour atteindre des profondeurs plus grandes que celles des niveaux de plage plus élevés. Les zones de dégel atteignirent des profondeurs plus importantes sur les cordons littoraux que sur les plages qui se prolongeaient par la toundra. A des niveaux de plage élevés, on n'enregistra pas de différences significatives entre la profondeur des zones de dégel et de celles de zéro degré de température, alors que, près du rivage, elles ne coïncidaient pas, à cause de la présence de pores d'eau salée entre les grains de sable.

Ревюме. Уровенъ мерзлоты и глубина оттаиванил арунта в приморской воне вблизи залива Пирд на Аляске. Глубина оттаивания грунта и подпочвенная температура ивмерялись вдоль четырех пересекающих пляжи линий в период с конца мая по конец августа. На поднятьх пляжах оттаивание грунта, после исчевновения снега с поверхности, идет вначале быстро, а ватем существенно замедляется. Пока море покрыто льдом оттаивание вблизи границы воды идет медленно, однако затем глубина оттаивания продолжает непрерывно расти, достигая болышей величины, чем на поднятых пляжах. Глубина оттаивания на береговых барах больше, чем на отбрежьи. На поднятых пляжах глубина оттаивания мало отличается от нулевой глубины, тогда как вблизи границы воды эти величины разнятся из-за присутствия соленой поровой воды.

\section{INTRODUCTION}

From studies undertaken by Rex (1964) and by Rogers et al. (1975) near Barrow, Alaska, by Owens and McCann (1970) and by McCann and Hannell (1971) in the Canadian Arctic, it has been shown that permafrost exists beneath the intertidal zone. Rex (1964) showed that the thaw depth fluctuates seasonally from $0-76 \mathrm{~cm}$ in early summer to greater than $150 \mathrm{~cm}$ in late August. In the Canadian Arctic, maximum depths of $60 \mathrm{~cm}$ were measured in late August (McCann and Hannell 1971). Data subsequently obtained from other sites in the Canadian Arctic (Taylor and McCann 1974) indicate maximum depths

${ }^{1}$ Coastal Studies Institute, Louisiana State University, Baton Rouge, Louisiana 70803, U.S.A. 
greater than $90 \mathrm{~cm}$ and show that in early summer the thaw zone is shallowest near the low-water mark, but that by late summer it is deepest in this section of the beach.

The present study was carried out between 24 May and 29 August 1976 in the littoral zone near Peard Bay, on the Chukchi Sea coast of Alaska (Fig. 1), with the object of determining: how rates of thaw in the littoral zone on this coast compare to previously reported thaw rates; whether any variations exist in the depth of thaw across the beach; and whether any alongshore variations exist in the depth of thaw.

The Peard Bay coast is a micro-tidal environment in which the tidal range of $0.25 \mathrm{~m}$ can be overshadowed by meteorological surges of up to $2 \mathrm{~m}$. The beaches and the barrier spit were low, their maximum elevations being two metres above mean water level. Littoral zone sediments at each site were poorly or moderately sorted, in the sand-pebble-cobble size range.

To avoid any confusion in terminology, in this study the frost table is defined as the $0^{\circ} \mathrm{C}$ isotherm (Fig. 2) (Mackay 1977). The location of this isotherm may coincide with, or lie above, the upper surface of ice-bonded material, depending on the water content of the sediments and on the salinity of the pore water. The thaw depth refers to the depth from the beach surface to the upper limit of icebonded material (ice-bonded surface in Fig. 2).

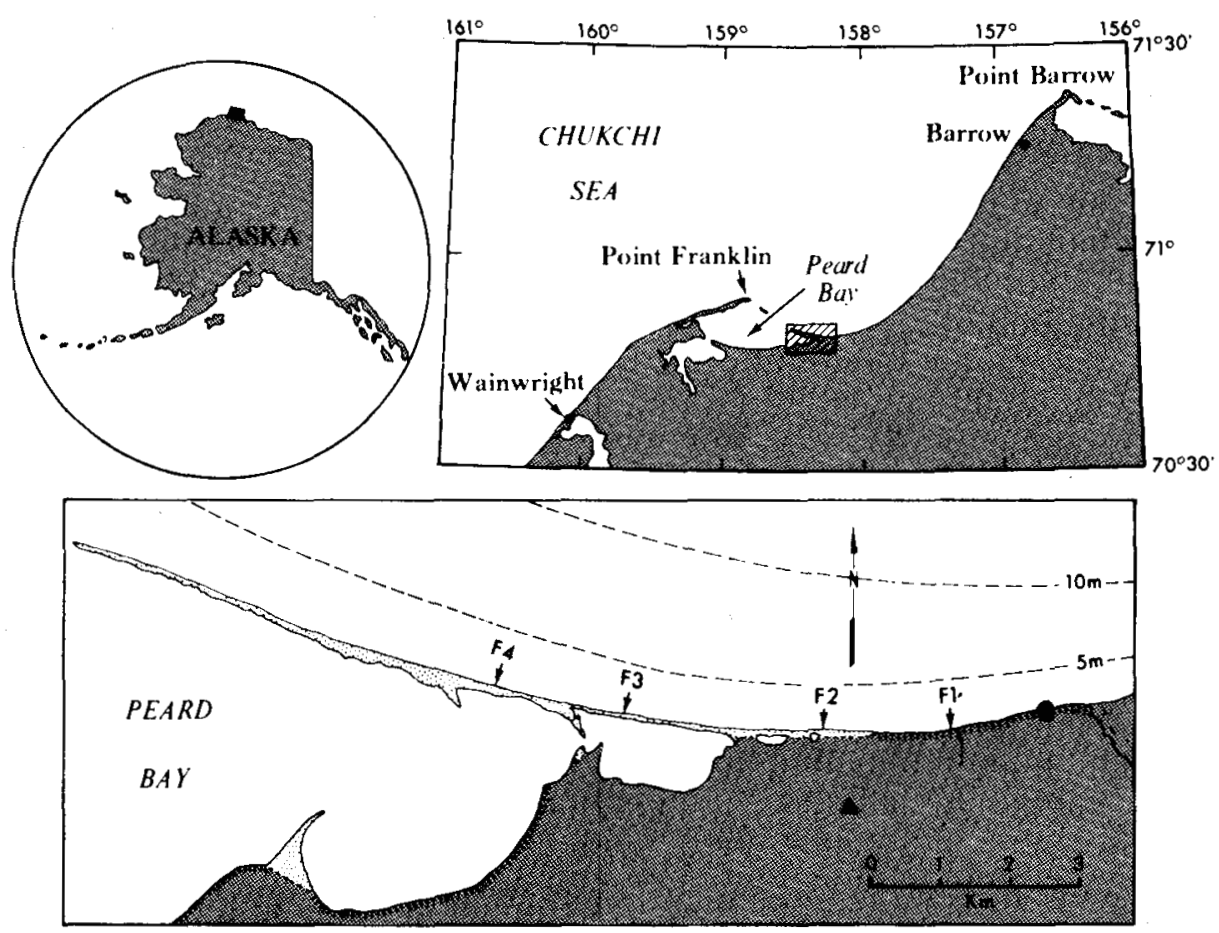

FIG. 1. The study area and measurement sites. The dot to the right of site F1 indicates the location of thermistor rod A; the triangle marks the site of the meteorological instrumentation; and the hachures indicate tundra cliffs. 


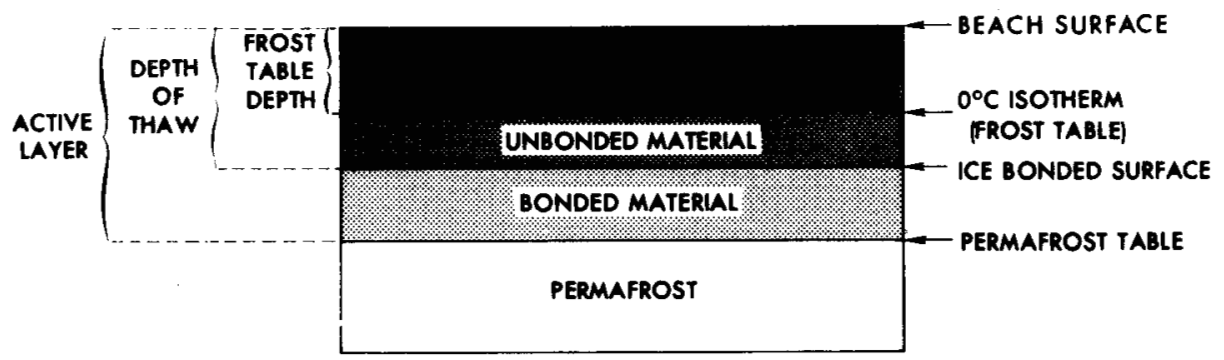

FIG. 2. Diagrammatic key to terms used.

\section{METHOD}

Frost-table depths were recorded daily from two thermistor rods, one of which was installed in the lower beach-face at the base of an adjacent tundra cliff (rod A, Fig. 1), and the other in the upper beach-face on profile F2 (rod B). Thaw depths were measured regularly throughout the study period by mechanical probing at an interval of $3 \mathrm{~m}$, from the backshore across the beach to the low-water line, along four profile lines: F1 - at the base of a two-metre-high tundra cliff across a 25-m-wide beach; F2 - across a 45-m-wide beach backed by flat tundra; F3 across a 55-m-wide barrier spit backed by a shallow lagoon; and F4 - across a 90-m-wide barrier spit backed by an open bay (Fig. 1). Profiles of the beach surface were surveyed using the pole-and-horizon method (Emery 1961), and profiles were connected by levelling. Meteorological data (air temperature, net radiation, soil heat flux, wind velocity and wind direction) were recorded continuously at a meteorological station $1.5 \mathrm{~km}$ inland from the coast (Fig. 1).

\section{RESULTS}

The Julian days (J) referred to below, and indicated in the corresponding figures and tables, are numbered consecutively from 1 January (1976).

\section{Air temperature and net radiation}

Air temperature was recorded on a Bendix Corporation recording thermograph. Comparison with the mean monthly values obtained with those for Peard

TABLE 1. Meteorological data

\begin{tabular}{lcccccc}
\hline & \multicolumn{3}{c}{$\begin{array}{c}\text { Mean monthly temperature } \\
\left({ }^{\circ} \mathrm{C}\right)\end{array}$} & & \multicolumn{3}{c}{$\begin{array}{c}\text { Daily mean radiation } \\
\text { (Kilojoules per sq cm per day) } \\
\text { with standard deviation } \\
\text { in parentheses }\end{array}$} \\
\cline { 2 - 3 } & $\begin{array}{c}\text { Barrow } \\
1931-60\end{array}$ & $\begin{array}{c}\text { Peard Bay } \\
1958-63\end{array}$ & $\begin{array}{c}\text { Peard Bay } \\
1976\end{array}$ & & $\begin{array}{c}\text { Barrow } \\
1962-66^{*}\end{array}$ & $\begin{array}{c}\text { Peard Bay } \\
1976\end{array}$ \\
\hline June & 0.6 & 3.2 & 2.4 & & $0.91(0.48)$ & $1.56(0.56)$ \\
July & 3.9 & 5.6 & 6.7 & & $1.10(0.07)$ & $1.63(0.60)$ \\
August & 3.3 & 5.6 & 6.0 & & $0.66(0.05)$ & $1.37(0.37)$ \\
\hline
\end{tabular}

*Maykut and Church 1973. 


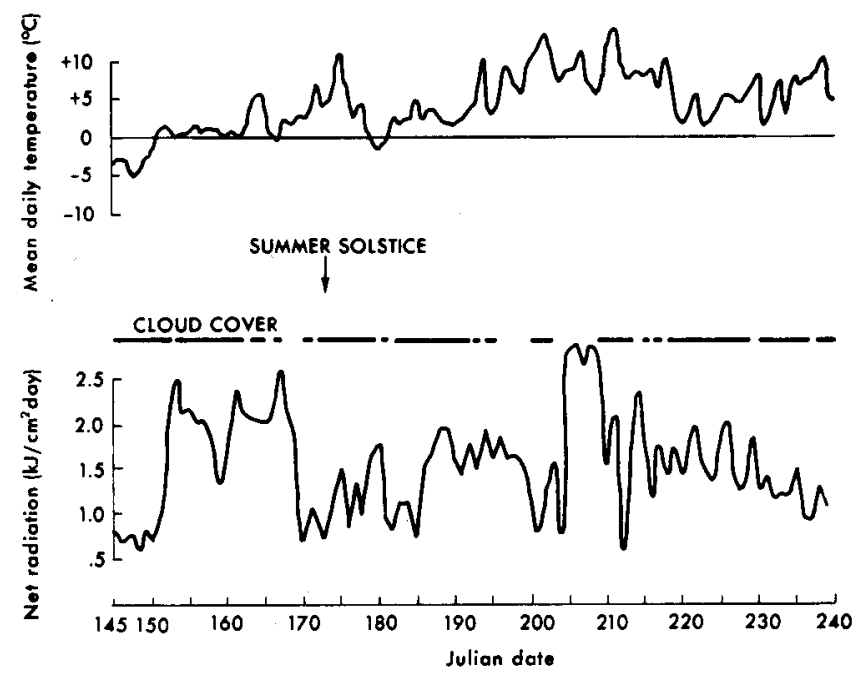

FIG. 3. Mean daily air temperatures $\left({ }^{\circ} \mathrm{C}\right.$ ) and values of net daily radiation (kilojoules per sq cm per day) as measured at the meteorological station (represented by the triangle in Fig. 2.) from 24 May (J145) to 27 August (J240). The elements of the horizontal broken bar indicate the periods when the cloud cover was greater than 50 per cent.

Bay in 1958-63 and Barrow in 1931-60 indicates that mean temperatures at Peard Bay in 1976 were slightly lower than normal in June but higher in July and August, and that Barrow has a slightly cooler climate than Peard Bay (Table1). Mean daily temperatures rose above $0^{\circ} \mathrm{C}$ on 30 May $(\mathrm{J} 151)$ but remained below $+2^{\circ} \mathrm{C}$ for the next ten days (Fig. 3). This period of initial above-zero-degree days coincided with the period of major snow melt over the tundra surface. A general warming trend followed $10 \mathrm{June}(\mathrm{J} 162)$, and there were only three days when recorded air temperatures fell below $0^{\circ} \mathrm{C}$ during the remainder of the study period.

Net radiation was recorded continuously at the meteorological station using a Thornthwaite miniature net radiometer located on the tundra surface. Comparison of the data obtained with those for Barrow (Maykut and Church 1973) shows that Peard Bay received significantly more radiation than Barrow usually receives during summer (Table 1) - which might be expected, since Barrow is on a peninsula and therefore very subject to summer fog.

At the beginning of the study, the net radiation values were very low (Fig. 3) because of the presence of nearly complete (over 90 per cent) snow cover. After 29 May (J150) the snow cover melted rapidly and ceased to be a major influence on the net radiation values. The dominant features of the record following the snow-melt period were the pulses associated with low cloud cover (under 50 per cent). Major pulses occurred between 31 May and 15 June (J152-J167) and between 23 July and 28 July (J205-J210).

Although the recordings of the net radiation were made $1.5 \mathrm{~km}$ inland from the beaches, and snow cover disappeared from the latter slightly before snow on the tundra melted (approximately 5-10 days earlier), thermistor rods at the recording station indicated the same rapid melt just after the study period commenced (J150). Since tundra and beach (gravel) albedos are similar (Sellers 1965), correlations may be made between initial thaw rates and net radiation over the tundra and over the beach study sites. 


\section{Thaw-depth profiles}

Thaw depths were measured on twelve occasions at sites $F 1$ and F2, and four of these profiles are shown on Fig. 4. Thaw depths were measured five times at sites F3 and F4, the profiles of which are shown on Fig. 5. The beach profile remained unchanged at all sites throughout the study period.

At site F1 the first survey, which took place on 26 May (J147) showed that the thaw depth was everywhere less than $15 \mathrm{~cm}$. Within 19 days, i.e., by 14 June (J166), the mean depth across the beach had increased from $3 \mathrm{~cm}$ to $54 \mathrm{~cm}$ (Fig. 6 and Table 2), and the thaw-depth profile virtually parallelled the surface profile. After 56 days, i.e., by 21 July (J203), the mean depth had increased to $71 \mathrm{~cm}$, and the thaw of the ice remained relatively constant, except in the lower beach face. Measurements that differed from the general trend were recorded $10 \mathrm{~m}$ landward of the water line and at the water line itself (Fig. 4). These could be due to either an ice lens in the beach or to a cobble that impeded the probe, or they may be true measurements of the location of the ice-bonded surface for which there is no readily apparent explanation. The last set of measurements, after 93 days, on 27 August (J240) indicates a mean depth across the profile of $111 \mathrm{~cm}$. This
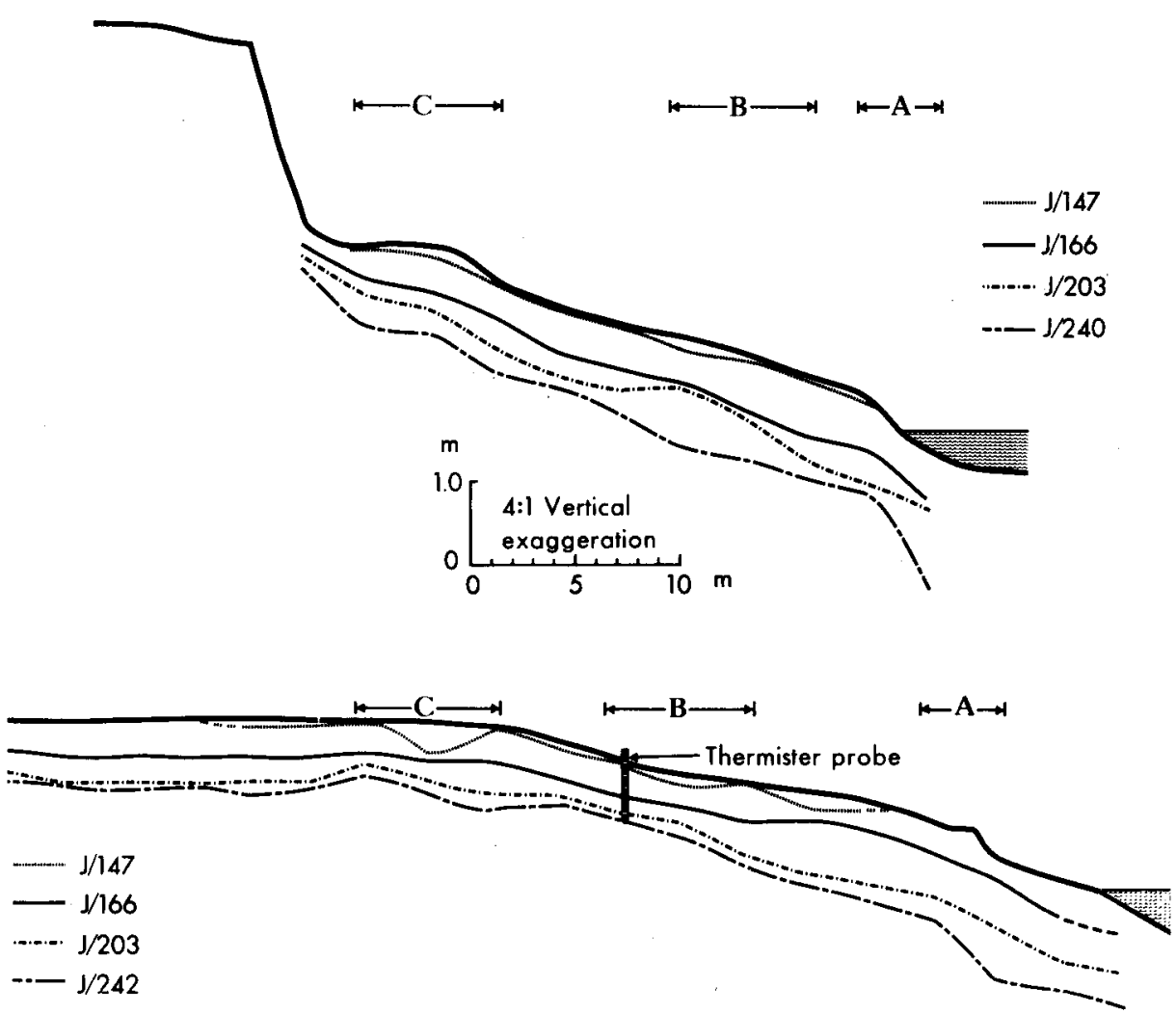

FIG. 4. Plots of depth-of-thaw profiles on selected dates. TOP - beach site F1; BOTTOM - beach site F2. The zones indicated on the plots are: A-lower beach face; B - upper beach face; and $\mathrm{C}$ - berm. 


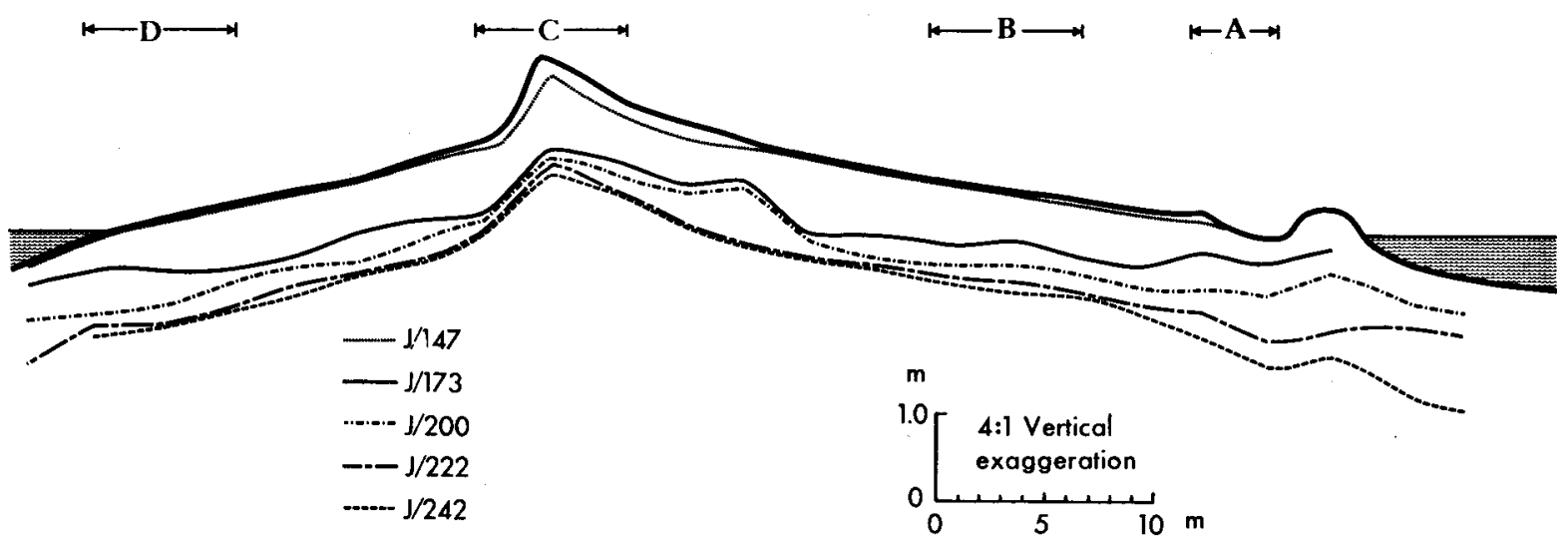

$\leftarrow D \rightarrow$

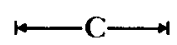

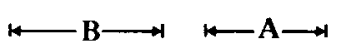

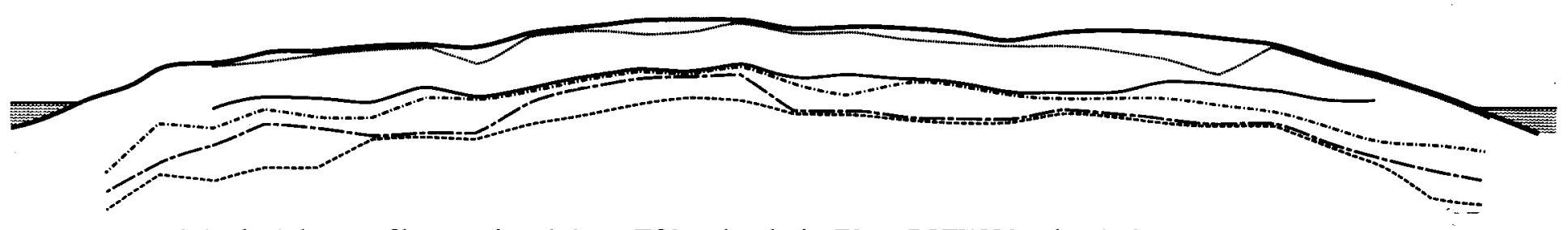

FIG. 5. Plots of depth-ot-thaw profiles on selected dates. TOP - beach site F3; - BOTTOM - beach site F4. The zones indicated on the plots are: $\mathrm{A}$ - lower beach face; $\mathrm{B}$ - upper beach face; $\mathrm{C}$ - berm; and $\mathrm{D}-$ beach face on the lagoon shore. 


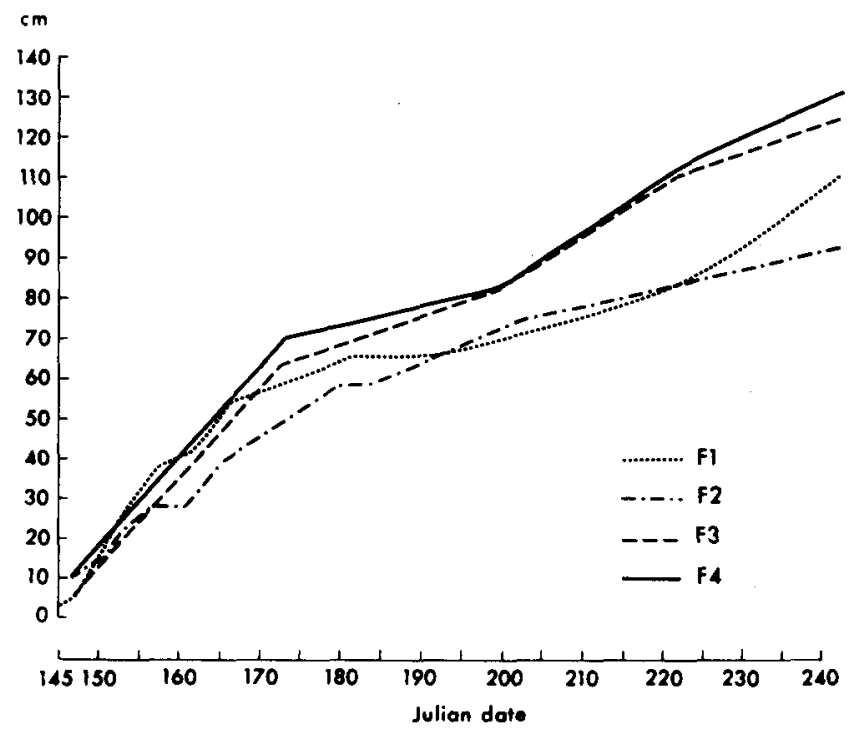

FIG. 6. Mean depths of thaw in centimetres from 24 May (J145) to 29 August (J242) at the four beach sites. The value at each site for a given date was obtained by computing the mean of all depths measured across the profile on that day.

TABLE 2. Depth of thaw on selected dates

\begin{tabular}{|c|c|c|c|c|c|c|}
\hline \multirow[b]{2}{*}{ Site } & \multirow{2}{*}{$\begin{array}{l}\text { Julian } \\
\text { date }\end{array}$} & \multicolumn{4}{|c|}{ Depth $(\mathrm{cm})$ in beach zones* } & \multirow{2}{*}{$\begin{array}{l}\text { Mean depth } \\
\text { across profile } \\
\text { (cm) }\end{array}$} \\
\hline & & $\mathbf{A}$ & B & C & D & \\
\hline F1 & $\begin{array}{l}166 \\
203 \\
240\end{array}$ & $\begin{array}{r}64 \\
91 \\
142\end{array}$ & $\begin{array}{r}65 \\
76 \\
124\end{array}$ & $\begin{array}{r}47 \\
72 \\
103\end{array}$ & - & $\begin{array}{r}54 \\
71 \\
111\end{array}$ \\
\hline $\mathbf{F} 2$ & $\begin{array}{l}166 \\
203 \\
242\end{array}$ & $\begin{array}{r}34 \\
87 \\
132\end{array}$ & $\begin{array}{l}44 \\
69 \\
82\end{array}$ & $\begin{array}{l}42 \\
68 \\
83\end{array}$ & - & $\begin{array}{l}40 \\
75 \\
93\end{array}$ \\
\hline F3 & $\begin{array}{l}166 \\
203 \\
242\end{array}$ & $\begin{array}{r}28 \\
82 \\
147\end{array}$ & $\begin{array}{r}48 \\
91 \\
115\end{array}$ & $\begin{array}{r}68 \\
100 \\
117\end{array}$ & $\begin{array}{r}43 \\
97 \\
146\end{array}$ & $\begin{array}{r}48 \\
87 \\
125\end{array}$ \\
\hline F4 & $\begin{array}{l}166 \\
203 \\
242\end{array}$ & $\begin{array}{r}34 \\
90 \\
131\end{array}$ & $\begin{array}{r}57 \\
97 \\
123\end{array}$ & $\begin{array}{r}54 \\
71 \\
115\end{array}$ & $\begin{array}{r}49 \\
88 \\
164\end{array}$ & $\begin{array}{r}55 \\
87 \\
131\end{array}$ \\
\hline
\end{tabular}

*See Figs. 4 and 5.

last data set is interesting because the thaw-depth profile parallels the surface profile except at the water line, where it drops sharply to a maximum recorded depth of $170 \mathrm{~cm}$. The sequence at this site is therefore one of relatively uniform increases in thaw depths across the profile following an initial high rate of thaw. An exception to this general trend occurred in the lower beach face where the depth of thaw increased after the melting or removal of the littoral-nearshore ice in mid-July (c. J200). This latter event led to a rapid increase in the depth of thaw in the zone near the water line, owing to the increases in subsurface temperatures or to salinity effects associated with the presence of seawater.

On site F2 the first survey, which also took place on 26 May (J147), again showed a very shallow depth of thaw (mean $10 \mathrm{~cm}$ ). Mean profile depths increased 
to $40 \mathrm{~cm}$ (J166), $75 \mathrm{~cm}$ (J203) and finally $93 \mathrm{~cm}$ (J242) (Fig. 6 and Table 2), and the thaw-depth profile had the same general characteristics as that of the beach surface (Fig. 4). Changes in mean depth of thaw were indicative of a rate of thaw that was initially high and decreased after mid-June (Fig. 6). Unlike at site F1, the rate of thaw did not increase again during the latter period of measurement, a fact which was a result of the difference in beach width between the two sites. At F1 the beach is narrow $(25 \mathrm{~m})$, and changes occurring near the water line affected the overall mean values; whereas at F2 the beach is $45 \mathrm{~m}$ in width, and increases in depth near the water line were insufficient to affect mean values. When the measurements from site F2 are grouped as shown in Fig. 7, it is evident that the presence of ice in the foreshore initially delayed thaw. Once

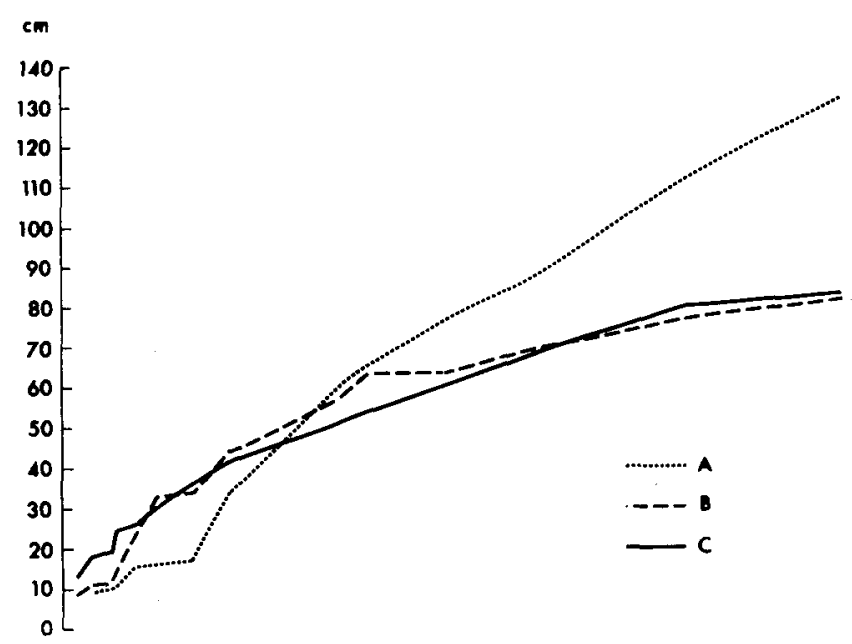

FIG. 7. Mean depths of thaw in centimetres by beach zone (as indicated on Figs. 4 and 5) from 24 May (J145) to 29 August (J242). TOP - site F2; BOTTOM site F3.

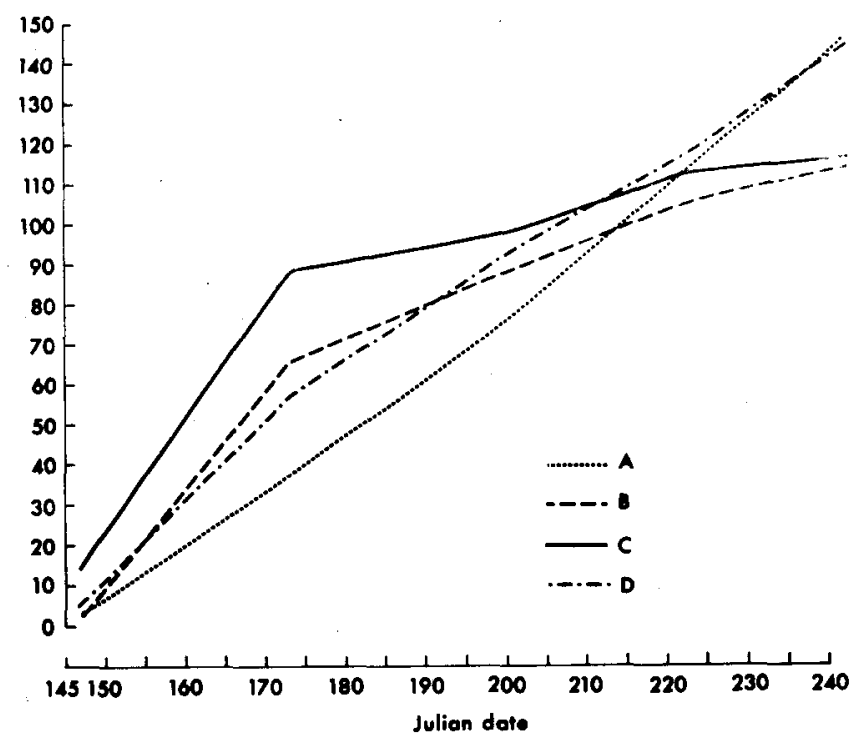


the sea ice had melted or left the beach, the presence of seawater caused a steady increase in the depth of the thaw, which continued after the rate had slowed on the upper parts of the beach. Again it appears that the initial thaw of the beach is closely related to melting of the snow cover and to net radiation values, whereas in the lower beach face the influence of seawater has a marked effect on the rate of the thaw following break-up.

The trends at sites F3 and F4 were similar to those at F1 and F2 (see Figs. 5 and 7). The shallow thaw zone rapidly increased in depth initially, at the same general rates as those at F1 and F2 (Fig. 6). After mid-June, the rates of increase in depth decreased, but not to the same degree as at F1 and F2. Following the break up of the sea ice, which occurred in mid-July (c. J200), the rate of thaw increased once more, as the presence of relatively warm saline seawater caused subsurface ground temperatures to be raised and the interface freezing point to be lowered. Because sites F3 and F4 were located on a barrier spit, the thaw depths increased with distance from the berm (beach zone $\mathrm{C}$ ) toward the lagoon and the sea (Fig. 5). The thaw depth at the berm was greater at these two sites than at F1 and F2, a fact which may be due to the warmer air and ground temperatures associated with the presence of water on both sides of the beach or to the presence of saline pore waters. By the end of the study period (J242) mean depths of thaw on the berm were $117 \mathrm{~cm}$ on profile $\mathrm{F} 3$ and $115 \mathrm{~cm}$ on profile $\mathrm{F} 4$, as compared to $103 \mathrm{~cm}$ and $83 \mathrm{~cm}$ on $F 1$ and $F 2$, respectively (Table 2).

On the upper beach face (zone B) and berm crest (zone C) of profile F3 (Fig. 5) thaw-rate curves (Fig. 7) show a similar trend to the time-dependent form discussed by Kelley and Weaver (1969). Zones A and D (lower beach sections) do not show the more typical exponential thaw rate, but rather have a nearly-uniform rate.

\section{Frost-table data}

The depth of the frost-table was determined by means of the thermistor rods installed in the beaches (see Fig. 1). These rods incorporated precision-resistance thermistors which were read daily by means of a wheatstone bridge. On rod A thermistors were set at 0,30 and $90 \mathrm{~cm}$, and on rod $B$ at $0,15,30$ and $60 \mathrm{~cm}$. The position of the frost-table was determined by linear interpolation between adjacent thermistors that recorded respectively above and below the $0^{\circ} \mathrm{C}$ value. When the lowest thermistor on the rods recorded a value greater than $0^{\circ} \mathrm{C}$ (i.e., the lowest thermistor was situated above the frost-table), the zero-degree depth was estimated by linear extrapolation from the temperatures recorded by the two lowest thermistors.

Rod A and rod B were installed into the beach face at $3 \mathrm{~m}$ and $20 \mathrm{~m}$ landward of the mean water line, respectively (see Figs. 1 and 4). The zero-degree depth recorded on rod A remained at the beach surface until 4 June (J156) when the surface snow cover melted (Fig. 8). Thereafter an initially rapid, and later steady, increase in the depth of the zero-degree surface accompanied nearshore ice melt and break-up. The large variations which occurred at about 20 August (J233) resulted from swash reaching the thermistor rod. Rod B, by contrast, indicated an early rapid increase in the zero-degree depth after thaw commenced on 29 
TABLE 3. Comparison of probe data and thermistor rod data

\begin{tabular}{|c|c|c|c|c|c|c|c|c|c|}
\hline \multirow[b]{2}{*}{$\begin{array}{l}\text { Julian } \\
\text { date }\end{array}$} & \multicolumn{4}{|c|}{ At tundra cliff site $(\operatorname{rod} A)$} & \multicolumn{5}{|c|}{ On upper beach face, site F2 (rod B) } \\
\hline & $\begin{array}{l}\text { Frost } \\
\text { table } \\
\left(0^{\circ} \mathrm{C}\right) \\
\text { depth } \\
(\mathrm{cm})\end{array}$ & $\begin{array}{l}\text { Probed } \\
\text { thaw } \\
\text { depth } \\
\text { (cm) }\end{array}$ & $\begin{array}{l}\text { Estimated } \\
\text { temperature } \\
\text { at probed } \\
\text { thaw depth } \\
\left({ }^{\circ} \mathrm{C}\right)\end{array}$ & $\begin{array}{c}\text { Estimated } \\
\text { salinity } \\
\text { of pore } \\
\text { water } \\
\% \text { oo }\end{array}$ & $\begin{array}{l}\text { Julian } \\
\text { date }\end{array}$ & $\begin{array}{l}\text { Frost } \\
\text { table } \\
\left(0^{\circ} \mathrm{C}\right) \\
\text { depth } \\
(\mathrm{cm})\end{array}$ & $\begin{array}{l}\text { Probed } \\
\text { thaw } \\
\text { depth } \\
\text { (cm) }\end{array}$ & $\begin{array}{c}\text { Estimated } \\
\text { temperature } \\
\text { at probed } \\
\text { thaw depth } \\
\left({ }^{\circ} \mathrm{C}\right)\end{array}$ & $\begin{array}{c}\text { Estimated } \\
\text { salinity } \\
\text { of pore } \\
\text { water } \\
\% \%\end{array}$ \\
\hline J166 & 29 & 31 & -0.28 & 5 & $\mathrm{~J} 147$ & 0 & 5 & & \\
\hline $\mathrm{J} 177$ & 40 & 62 & -1.55 & 28 & $\mathrm{~J} 149$ & 0 & 2 & & \\
\hline $\mathrm{J} 184$ & 46 & 78 & -2.10 & 38 & $\mathrm{~J} 151$ & 17 & 3 & & \\
\hline $\mathrm{J} 192$ & 60 & 79 & -1.39 & 26 & $\mathrm{~J} 152$ & 14 & 20 & -0.7 & 13 \\
\hline \multirow[t]{10}{*}{$\mathrm{J} 203$} & $94^{*}$ & 84 & & & J154 & 18 & 20 & -0.1 & 2 \\
\hline & & & & & J157 & 29 & 30 & -0.1 & 2 \\
\hline & & & & & J161 & 31 & 33 & -0.09 & 2 \\
\hline & & & & & J166 & 41 & 44 & -0.4 & 8 \\
\hline & & & & & $\mathrm{J} 180$ & 50 & 54 & -0.5 & 9 \\
\hline & & & & & $\mathrm{J} 183$ & 49 & 58 & -1.0 & 18.5 \\
\hline & & & & & J192 & 53 & 60 & -0.8 & 15 \\
\hline & & & & & $\mathrm{J} 203$ & $63^{*}$ & 64 & & \\
\hline & & & & & $\mathrm{J} 222$ & $73^{*}$ & 71 & & \\
\hline & & & & & $J 242$ & $75^{*}$ & 72 & & \\
\hline
\end{tabular}

*Estimated by extrapolation (see text). 
May (J150). This rapid increase was associated with the onset of above-zerodegree days and with a large pulse of net radiation (Fig. 3). The initial rapid rise appears to have been more closely associated with the radiation pulse, which reflects the rapid snow melt and the low cloud cover, than with the more gradual increase in air temperature. The thaw rate declined and then levelled off after 28 July (J210), with estimated values oscillating between $70 \mathrm{~cm}$ and $80 \mathrm{~cm}$.

Comparison of the thermistor data with results of the probe study suggests that in the upper beach face (thermistor rod B) the zero-degree depth and the probe depth are almost identical. Closer to the swash zone (thermistor rod A) the probe depths are generally greater than the zero-degree depth (Table 3). This latter difference is probably due to salinity intrusions of the nearshore "moat" water prior to break-up.

If the measured values for zero-degree depth and for depth of thaw do not coincide, it is possible to make estimates of the salinities at the bonded-unbonded interface, assuming saturation is complete. Data from the thermistor rods may be used to estimate the temperature at the probed depth, i.e., at the bonded-unbonded interface (Table 3). Temperatures below $0^{\circ} \mathrm{C}$ are assumed depressed because of the presence of salts, and the salinities may then be estimated from the depressed freezing point (Neumann and Pierson 1966). Salinity estimates are listed in Table 3 and suggest both temporal and spatial variations. Pore waters at the interface on thermistor rod A were initially fresh, but rapidly became more saline after 25 June ( $\mathrm{J} 177)$ as the nearshore moat developed and nearshore waters communicated freely with offshore saline waters. The high estimated salinity value for rod $A$ on 2 July (J184) could have been due to the presence of brine, but it is more likely to have been the result of a discrepancy between the measured probe depth and the estimated interface temperature. Measurements on thermistor rod B, located in the upper beach face, showed lower estimated salinities, except on 26 and 28 May (J147 and J149) when an unbonded, unsaturated surface layer was apparently penetrated. Estimated salinity values showed a moderate increase over the remainder of the study period. As no swash reached this location during the study, the increase in salinities might be due to diffusion of salt from the nearshore water or to release of brine pockets trapped in the ground ice during the previous winter.

\section{DISCUSSION}

It is evident that increasing temperature and net radiation, decreasing snow cover, and the presence of open water in the nearshore zone, were the major factors bringing about a lowering of the frost-table and an increase in the depth of thaw. High net radiation was responsible for the rapidity of the thaw just after the snow cover melted, but the rate of the thaw became slower after the middle of June (J165-J170). Later, open-water conditions were responsible for the variations in the frost-table and thawed-ground depths across the beach and along the shore.

In the lower beach face the frost-table was at or near the surface until the snow melted. The rate of thaw remained low until the beach-fast ice had melted and 


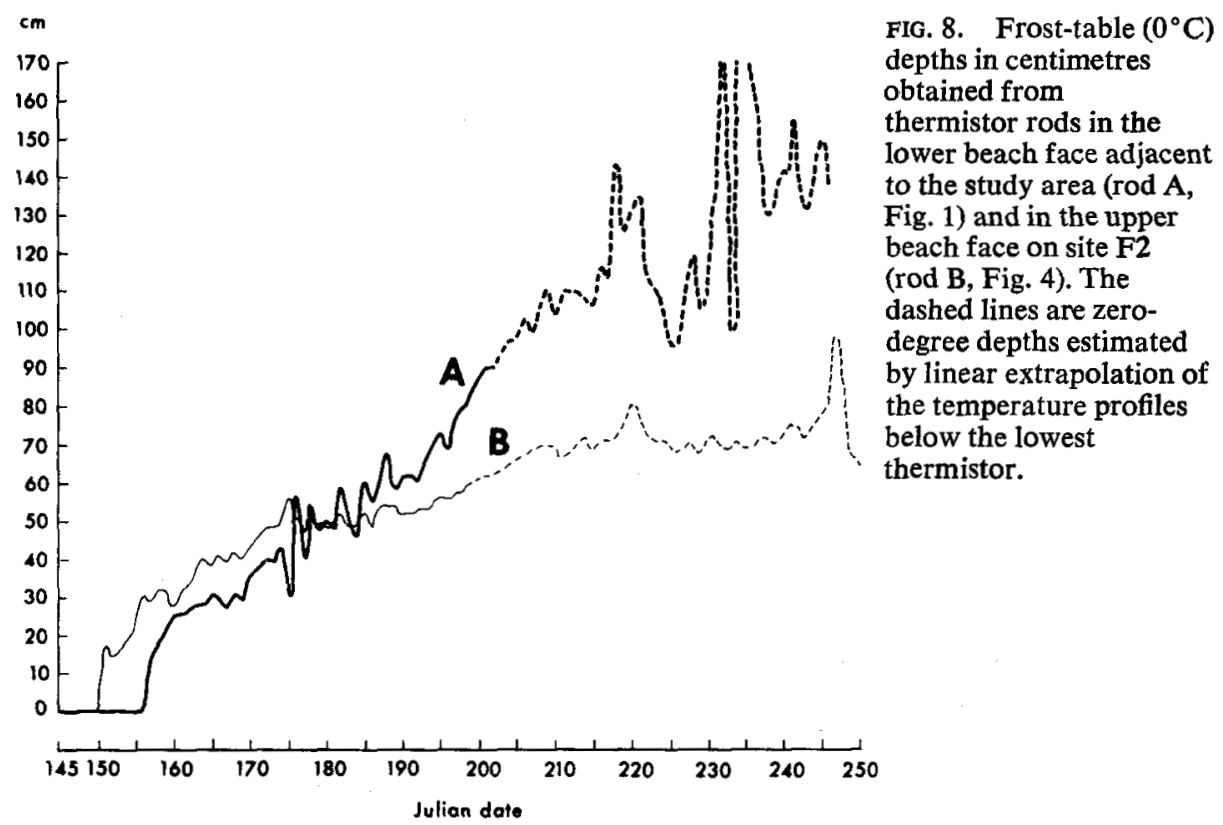

break-up commenced. Once seawater infiltrated the beach, the thaw became rapid and the frost-table moved down to depths of $125-175 \mathrm{~cm}$ (see Figs. 7 and $8)$. The thermistor rod installed in the lower beach face (rod A) registered large changes in the zero-degree depth that were related to observed differences in swash height.

On the upper beach face and on the berm the frost-table was again at or near the surface until the snow cover melted. Melt coincided with a large pulse of net radiation between 29 May (J150) and 18 June (J170), and the frost-table moved rapidly down until net radiation values dropped to below two kilojoules per square centimetre per day, after which the frost-table dropped only very slowly (see Figs. 7 and 8). It appears that, once the thaw had progressed in this area to below a depth of about $60-70 \mathrm{~cm}$, changes in the levels of net radiation, such as the pulse that occurred between 23 July and 28 July (J205-J210), no longer affected the ice-bonded material or the zero-degree level (see Fig. 3). The depth at which the frost-table is no longer affected by variations in levels of net radiation is probably a function of the thermal conductivity of the beach sediments.

Across-the-beach variations were particularly evident at sites F3 and F4 where there is a beach on either side of the berm (Fig. 7). At all sites the rate of thaw in the lower beach face was initially slower, but subsequently faster, than in the upper beach face and on the berm - a finding which agrees with the results of Taylor and McCann (1974). In addition, there was an alongshore variation at the study site inasmuch as thaw depths were generally lower on the spit (Fig. 6) than on the beaches backed by cliffs or low tundra, owing to the greater effect of seawater.

Although the present study covered only part of the annual beach cycle, and was completed before freeze-up commenced, data presented by Short (1973) 
indicate that the beach surfaces refreeze with the onset of "freeze days" (days on which the air temperature does not rise above $0^{\circ} \mathrm{C}$ ) and that freezing of the beach proceeds downwards from the surface, eventually reaching the permafrost. The beach surface may re-thaw if temperatures rise above freezing, but Short states that in Alaska the freeze-thaw oscillations cease by early September on the Beaufort Sea coast and the northwestern Arctic coast, and by late September on the southwestern Arctic coast.

Ice in beaches may act as a lower limit for wave action (Owens and McCann 1970), but the presence of water at temperatures above $0^{\circ} \mathrm{C}$ has a very marked effect on ice, and leads to rapid melting. Therefore, if the beach is eroded to or near the depth of thaw during storms, the presence of seawater will cause further downward movement of the thaw zone. In this case, the presence of ice only delays erosion, rather than preventing further redistribution of sediment. The effects of ice beneath barrier islands or spits (McDonald et al. 1973) with respect to long-term barrier stability are uncertain, but they do not preclude inlet development by breaching on polar beaches. Several examples are known on the Arctic coasts of Alaska of storms or river run-off having opened inlets in a barrier (see Short 1973 p. 92).

\section{CONCLUSIONS}

1. Thaw of ice-bonded sediments in the upper beach face commences after the surface snow cover melts. An initial high rate of thaw is followed by a decrease in the downward migration rate of the thaw zone after mid-June.

2. Thaw of ice-bonded sediments in the lower beach face is delayed by the presence of an ice foot. Once the latter melts, the thaw is rapid and the thawed zone extends to greater depths than on the upper beach face or the berm.

3. Thaw depths are greater on barrier beaches backed by lagoons than on beaches backed by tundra or by cliffs.

4. The initial downward migration of the $0^{\circ} \mathrm{C}$ isotherm is more closely related to net radiation than to air-temperature values.

5. On the upper beach and the berm the depth of thaw and the frost-table depth are generally coincident. In the lower sections of the beach the depth of thaw is greater as a result of the effects of saline seawater that both reduces the freezing point of the pore water to below $0^{\circ} \mathrm{C}$ and removes more heat from the sediments because of its high heat capacity.

\section{ACKNOWLEDGEMENTS}

The research was performed under a contract with Geography Programs, Office of Naval Research, Arlington, Virginia 22217. The logistic support of the Naval Arctic Research Laboratory at Point Barrow, Alaska, is greatly appreciated. Rodney Fredericks, Pat Harper and William J. Wiseman, Jr. assisted with the data collection. J. Brown (Cold Regions Research and Engineering Laboratory, Hanover, New Hampshire) reviewed the original manuscript, and his comments and criticisms greatly improved the text discussion. Research support was also provided by a contract with Arctic Programs, Office of Naval Research, Arlington, Virginia 22217. 


\section{REFERENCES}

EMERY, K. O. 1961. A simple method of measuring beach profiles. Limnology and Oceanography, 6: 90-93.

KelleY, J. J., JR., and WeAver, D. F. 1969. Physical processes at the surface of the Arctic tundra. Arctic, 22: 425-37.

MACKAY, J. R. 1977. Probing for the bottom of the active layer. Canada, Geological Survey, Report 77-1A. pp. 327-8.

MAYKUT, G. A. and CHURCH, P. E. 1973. Radiation climate of Barrow, Alaska, 1962-1966. Journal of Applied Meteorology, 12: 620-8.

MCCANN, S. B. and HANNELL, F. o. 1971. Depth of the "frost table" on Arctic beaches, Cornwallis and Devon Islands, N.W.T., Canada. Journal of Glaciology, 10 (58): 155-7.

MCDONALD, B. C., EDWARDS, R. E. and RAMPTON, v. N. 1973. Position of frost table in the near-shore zone, Tuktoyaktuk Peninsula, District of Mackenzie. Canada, Geological Survey, Paper 73-1, part B. pp. 165-8.

NEUMANN, G. and PIERSON, W. J., JR. 1966. Principles of Physical Oceanography. Englewood Heights, New Jersey: Prentice-Hall. p. 43.

OWENS, E. H. and MCCANN, S. B. 1970. The role of ice in the arctic beach environment, with special reference to Cape Ricketts, southwest Devon Island, Northwest Territories, Canada. American Journal of Science, 268 (5): 397-414.

REX, R. W. 1964. Arctic beaches, Barrow, Alaska. In: Miller, R. L. (ed.), Papers in Marine Geology. New York: Macmillan. pp. 384-400.

ROGERS, J. C., HARRISON, W. D., SHAPIRO, L. H., OSTERKAMP, T. E., GEDNEY, L. D. and VAN WORNER, J. D. 1975. Nearshore Permafrost Studies in the Vicinity of Point Barrow, Alaska. Fairbanks: University of Alaska (Geophysical Institute, Report UAG R-237; Sea Grant Report 75-6).

SEllers, w.D. 1965. Physical Climatology. Chicago: University of Chicago Press.

SHORT, A. D. 1973. Beach dynamics and nearshore morphology of the Alaskan arctic coast. (Unpublished Ph.D. thesis, Louisiana State University, Baton Rouge, U.S.A.)

TAYLOR, R. B and MCCANN, S. B. 1974. Depth of the "frost table" on beaches in the Canadian Arctic Archipelago. Journal of Glaciology, 13 (68): 321-2. 